\title{
A Labor Law for the Digital Era
}

\author{
Katherine V. W. Stone
}

Published online: 19 March 2009

(C) The Author(s) 2009. This article is published with open access at Springerlink.com

Key words labor law $\cdot$ employment law $\cdot$ digital era

There is a serious problem with the labor and employment law system in the United States today. Unions have declined to the point where they represent less than $8 \%$ of the private sector workforce, employee wages have stagnated for more than three decades, employers are cutting back on workers' health insurance and pensions, and there is a dramatic growth in the numbers of the working poor. At the same time, there has been a rising chorus of complaints from labor scholars that the labor law has become "ossified" (Estlund 2002), that the law is failing to offer meaningful worker protection (Summers 1988; Gottesman 1993), that the courts and Labor Board have abandoned the "core values of labor law" (Dannin and Bonior 2006), and that Congress has defunded the labor protective agencies such as the National Labor Relations Board (NLRB), the Occupational Safety and Health Administration (OSHA) and the Hour and Wage Division that administers the Fair Labor Standards Act (FLSA) (Dannin 2004; Brudney et al. 1999; McGarity and Shapiro 1996). Indeed, some have contended that during the past two decades, there has been a passive repeal of the employment statutes (Hiatt and Becker 2005; Brudney 1996; Dannin and Bonior 2006; Stone 1992).

There is a reason that the field of labor and employment law has declined. Work itself has not declined in importance-it remains a central part of individual identity and a prominent aspect of social life, but the labor and employment laws do not address the concerns or vulnerabilities of the majority of the workforce today. Instead, the regulatory framework governing the workplace is becoming irrelevant.

K. V. W. Stone $(\triangle)$

UCLA School of Law, 405 Hilgard Ave., Los Angeles, CA 90024, USA

e-mail: stone@law.ucla.edu 
The question I address here is, how did the system come to this state and where is it going? In order to consider the future, one must develop an analytic and dynamic understanding of the present and the past. A future-oriented interpretation of the present and the past can help identify trends, provide a basis for critique, and suggest constructive directions for change.

\section{Labor and Employment Law in the Past}

The American system of employment regulation is a two-track system. "Labor law" provides the mechanism for collective bargaining and other forms of employee collective action, while "employment law" sets minimal employment standards for all employees. Employment laws set minimum wages, establish safety and health standards, provide old age assistance, require unemployment insurance, compensate industrial injuries, mandate child care and medical leave, and establish other minimal terms of employment. Because the employment law standards are generally meant to be floors, they do not obviate the need for workers to bargain, whether individually or collectively, for employment standards above the set minima. The two-track system of regulation reflects the American labor law's commitment to settling distributional issues through private bargaining and removing such issues from the political process.

The basic framework of today's labor and employment law originated in the New Deal period and was tailored to the job structures of that era. In that era, which I call the "industrial era" (Stone 2004), large firms organized their work forces into a set of practices that has come to be termed "internal labor markets" (Doeringer and Piore 1971). The term "internal labor market" is used to distinguish these practices from the neoclassical ideal of a large impersonal external labor market in which buyers and sellers contract freely and repeatedly for jobs of all types (Dunlop et al. 1988).

The internal labor market job structures of the industrial era developed in the early and midtwentieth century, based on the teachings of the scientific management and personnel management schools of thought (Stone 1975). In internal labor markets, jobs are organized along rigidly defined lines of promotion, called job ladders. Workers are hired at the lowest rungs and then advanced, step by step, throughout their careers. The internal labor market job structure assumed a long-term relationship between the employee and the firm. It also assumed that job tasks were minutely delineated and carefully arranged so that each job provided the training for the job on the next rung. Workers tended to stay within a particular department and on a single promotion line, and had little lateral mobility within or between firms. They were rewarded with longevity-based pay and benefits, and their seniority defined both their bidding rights for higher jobs and their bumping rights in case of reductions in force (Doeringer and Piore 1971, at 1-3; Stone 2004, at 53-56; Osterman 1984).

By the 1930s, scientific management had become business gospel, and internal labor markets had become widespread in large industrial firms. Also in that decade, three significant labor statutes were enacted that established a framework for governing labor relations, which persists to this day. ${ }^{1}$ This framework was appropriate to the long-term

\footnotetext{
${ }^{1}$ The Norris-LaGuardia Act of 1932 prevented federal courts from issuing injunctions in most labor disputes, 29 U.S.C. $\S \S 101-115$ (2000). The National Labor Relations Act (NLRA) of 1935 gave workers and enforceable right to engage in concerted action for mutual aid and protection, to organize unions of their own choosing, and to engage in collective bargaining, 29 U.S.C. $\S \S 151-169$ (2000). The Fair Labor Standards Act of 1938 established a federal minimum wage and set maximum hours for employment. 29 U.S.C. $\S \S$ 201-219 (2000).
} 
employment relationships in stable work environments that characterized the industrial era, and it was based on the template of the mid-twentieth century employment relationship. ${ }^{2}$

\section{The New Deal Collective Employment Law}

Industrial era assumptions were embodied in the National Labor Relations Act. For example, a central aspect of the statutory scheme is the concept of a "bargaining unit." Under the statute, if there is a sufficient showing of interest by workers in a particular workplace, the National Labor Relations Board (the NLRB or the Board) determines the "appropriate unit" and conducts an election among employees working in the unit to determine whether a majority favor the union. ${ }^{3}$ If the union wins the election, the union is certified and becomes the exclusive representative of the unit for purposes of collective bargaining. ${ }^{4}$ Once certified, the employer and the union have a duty to bargain for a collective agreement that will govern the terms and conditions of employment for all workers in the unit, regardless of whether the employees are union members or not. ${ }^{5}$ Any contract concluded between the union and the employer applies to all jobs in the unit. The terms and benefits applied to the job-they do not follow the worker to other jobs when they leave the unit. At the same time, workers in the unit lose their right to take collective action apart from their certified representative, ${ }^{6}$ and the union has a duty to represent fairly all employees in the unit- those that support the union and those that do not. ${ }^{7}$

The agency that administers the Act, the National Labor Relations Board, determines on a case by case basis what constitutes an appropriate bargaining unit. The Board does so by attempting to define units of employees who share a "community of interest." Some of the factors the Board uses to determine whether there is a community of interest are: similarity in kinds of work performed, similarity in compensation, types of training and skills required, integration of job functions and commonality of supervision. ${ }^{8}$ Under the community of interest test, bargaining units tend to have static job definitions and clear department boundaries. Yet, much of today's work involves networks across multiple establishments or multiemployer tasks, defying traditional bargaining unit definitions. Thus the NLRB's approach to bargaining unit determination is in tension with cross-utilization and the blurring of boundaries typical of work practices today. ${ }^{9}$

The bargaining unit focus of the NLRA also means that terms and conditions negotiated by labor and management apply to the jobs in the unit rather than to the individuals who hold the jobs. As individual workers move between departments, units, or firms, their labor

\footnotetext{
${ }^{2}$ For a detailed description of the 20 th century employment relationship, see Stone 2004, at 27-63.

329 U.S.C. § 159(b).

${ }^{4}$ Under the National Labor Relations Act (NLRA), a union can also be designated as an exclusive representative by means of an employer grant of recognition after a showing of a card majority or other convincing evidence of majority support. See NLRB v. Gissel Packing Co., 395 U.S. 575, 592 (1969). But certification as a result of a Board-sponsored election is the preferred method of obtaining representative status under the NLRA. See id. at 596.

${ }^{5}$ See Steele v. Louisville \& Nashville R.R. Co., 323 U.S. 192, $200-04$ (1944).

${ }^{6}$ See Emporium Capwell Co. v. W. Addition Cmty. Org., 420 U.S. 50, 64, 69-70 (1975).

${ }^{7}$ See Vaca v. Sipes, 386 U.S. 171, 177, 182 (1967); Steele, 323 U.S. at 200-02.

${ }^{8}$ See NLRB v. Action Auto., Inc., (1985); NLRB v. Purnell's Pride, Inc., (1980). See generally Getman et al. (1999).

${ }^{9}$ See Colvin (1998) (noting that changes in the nature of employment create problems for bargaining unit determination).
} 
contracts do not follow them. Yet, today individuals experience considerable movement in their work lives, both within firms, between firms, and in and out of the labor market. As a result, in today's world of frequent movement, union gains are increasingly ephemeral from the individual's point of view.

Another way in which the NLRA assumes the existence of industrial era job structures is found in the scope of the Act's coverage. The Act only provides protections for those individuals who fall within the statute's definition of an "employee." Individuals who work for multiple employers or the wrong kind of employer can easily fall outside the protection of the statute. Agricultural laborers, domestic workers, supervisors and independent contractors are explicitly excluded from the Act, as are government employees and employees covered by the Railway Labor Act. ${ }^{10}$ There are additional NLRB-made exclusions for managerial and confidential employees. ${ }^{11}$ Furthermore, employees who have some supervisory authority over others, or who have managerial decisions delegated to them, are excluded from coverage. ${ }^{12}$ In today's workplace, in which hierarchies have been flattened and decision-making authority has been delegated downward, the supervisory and managerial exclusions deprive many low-level employees of the protections of the Act. ${ }^{13}$

The exclusion for independent contractors has become particularly problematic. Because the test for independent contractor status is broad, many who are dependent on a particular employer for their livelihood are nonetheless classified as independent contractors and deprived of all labor law protections. ${ }^{14}$ Increasingly, employers attempt to reclassify employees and to vary their employment practices to transform their former "employees" into "independent contractors." ${ }^{15}$ Many low-paid employees such as janitors, truck loaders, typists and building cleaners have been redefined as independent contractors even when they are retained by large companies to work on a regular basis.

The independent contractor exclusion also eliminates coverage for many part-time and short-term temporary workers. ${ }^{16}$ Such workers often work for more than one employer at a time, but are dependent upon and subject to the supervision of each employer for the time they are at work. Yet, when a worker has multiple employers, each employer often uses that fact to argue that the worker is actually an independent contractor rather than an employee.

\footnotetext{
${ }^{10}$ See 29 U.S.C. $\S \S 152(2),(3)$.

${ }^{11}$ See NLRB v. Hendricks County Rural Elec. Membership Corp., 454 U.S. 170, 177-85 (1981) (sustaining the Board's creation of confidential exclusion); NLRB v. Bell Aerospace Co., 416 U.S. 267, 289 (1974) (sustaining managerial exclusion); In re Ford Motor Co., 66 NLRB 1317, 1322 (1946) (confidential exclusion).

${ }^{12}$ See NLRB v. Health Care \& Ret. Corp., 511 U.S. 571, 578 (1994) (finding that charge nurses are "supervisors" under the statute because they assign work to nurse's aides); NLRB v. Yeshiva Univ., 444 U.S. 672, 679-82 (1980) (holding that university professors are "managers" for purposes of exclusion because they exert collective decision-making authority in hiring, curriculum, and other matters).

${ }^{13}$ See, e.g., NLRB v. Ky. River Cmty. Care, Inc, 532 U.S. 706 (2001) (finding certain nurses to be "supervisors" even though they had no subordinates and had no authority to hire, fire, promote, reward, or evaluate other employees).

${ }^{14}$ See generally Stone (2006b).

${ }^{15}$ See Brustein (2005); Ball (2003). See also, Graditor (2003) (arguing that employers regularly misclassify employees as independent contractors to avoid paying unemployment insurance).

${ }^{16}$ In the 1947 amendment to section 2(2) of the NLRA, 29 U.S.C. $§ 152(2)$, Congress rejected an "economic reality" test in favor of a common law test for determining independent contractor status. However, the Board and courts of appeal have often differed as to what that test requires.
} 
Courts often accept the employer's own definition of a temporary worker's status, thereby excluding a fast-growing portion of the workforce from unionization altogether. ${ }^{17}$

One area in which the bargaining unit focus of the NLRA has been particularly out of step with labor market reality concerns the Act's treatment of long-term temporary employees. Since the 1980s, temporary employment has been the fastest growing portion of the labor market. Temporary employees who work for staffing agencies are often given long-term placement at particular user firms. There, the user firm supervises the work of the temp on a day-to-day basis, and the temp works alongside the firm's regular employees, with the same skills, duties, and job classifications. In this triangulated employment relationship, the NLRB has considered both the temporary agency and the user firm to be joint employers of the temporary employee.

In 1990, the NLRB ruled that long-term temporary employees could not be included in a bargaining unit with a user-employer's regular employees unless both the provider-agency employer and the user-employer consented. ${ }^{18}$ Thereafter, the Board refused to consider any unit that combined temporary and regular employees, absent consent of both employers. ${ }^{19}$ Because it is highly unusual for an employer to consent to its employees forming a union, the dual consent requirement made it virtually impossible for temporary workers to unionize together with permanent workers they work alongside. ${ }^{20}$ Rather, if they want to unionize, they must do so together with the other workers employed by their temporary agency. Yet agency temporary workers are dispersed and have little contact with each other. Thus, as a practical matter, temporary workers lack representation or a collective voice under the labor law.

\section{Individual Employee Rights}

The U.S. labor law creates a strict divide between labor law, which pertains to collective employee rights, and employment law, which pertains to individual employee rights. Under the bifold system, core labor policy is based on bargaining and contract, with a peripheral role for legislation that establishes employment terms. Yet many of the initial employment law entitlements assume the existence of an on-going employment relationship. For example, the New Deal social security and unemployment insurance programs were not universal in their coverage. Rather, they tied crucial social insurance protections to employment, thereby reinforcing the bond between the employee and the firm. Furthermore, they did not provide mandatory and universal health insurance. Thus workers were left to obtain health insurance from individual employers, usually as a product of labor-management negotiations.

Other types of employment law protections also assume an employment relationship and hence are not available to persons designated "independent contractors." Independent contractors are not covered by minimum wage, workers compensation, unemployment compensation, occupational safety and health laws, collective bargaining laws, social

\footnotetext{
${ }^{17}$ See, e.g., Clark v. E.I. DuPont de Nemours \& Co., 105 F.3d 646 (4th Cir. 1997) (per curiam); Abraham v. Exxon Corp., 85 F.3d 1126, 1132 (5th Cir. 1996). But see Vizcaino v. United States Dist. Court, 173 F.3d 713, 724-25 (9th Cir. 1999) (rejecting an employer's assertion that employees are independent contractors for purposes of eligibility for a stock purchase plan).

18 See Lee Hosp., 300 NLRB 947 (1990).

${ }^{19}$ See, e.g., Int'l Transfer of Fla., 305 NLRB 150 (1991).

${ }^{20}$ In 2000, the NLRB reversed its former position and held that regular employees and temporary employees could be in the same bargaining unit so long as they shared a community of interest. In re M.B. Sturgis, Inc., 331 NLRB 1298 (2000). However, in 2004 the NLRB again reversed itself in the case of Oakwood Care Center and $N \& W$ Agency, and reinstated the dual consent requirement for temporary worker organizing efforts. 343 NRLB No. 76 (2004).
} 
security disability, anti-discrimination laws, or any of the other employment protections discussed above. ${ }^{21}$ Unlike Europe and Canada, in the United States there have not been legislative efforts to create an intermediate category between "employee" and "independent contractor" that would give atypical workers some of the employment protections available for standard workers. ${ }^{22}$

\section{The Demise of the New Deal System and the State of Labor and Employment Law Today}

Because the labor and employment laws were tailored to the job structures of the industrial era of the twentieth century, they have become obsolete as internal labor markets have declined in importance and new ideas about how to organize work have generated new work practices throughout American enterprises. Job security in the private sector, in the form of long-term attachment between a worker and a single firm for the duration of the worker's career, is rapidly declining. ${ }^{23}$ Today workers expect to change jobs frequently and employers engage in regular churning of their workplace, combining layoffs with new hiring as production demands and skill requirements shift. "Regular" full-time employment no longer carries the presumption of a long-term attachment between an employee and a single firm with orderly promotion patterns and upwardly rising wage patterns. At the same time, employers encourage employees to manage their own careers and not to expect career-long job security. ${ }^{24}$ In addition, there has been an explosion in the use of atypical workers such as temporary workers, on-call workers, leased workers, and independent contractors.

A new employment relationship is emerging to replace the industrial era internal labor markets. Today's world of specialty production and knowledge work has spurred the development of new job structures, the job structures of the "digital era." In the digital era, employees do not have long term job security with a particular employer. Some of the terms of the new employment relationship are as follows:

First, instead of job security, employers today explicitly or implicitly promise to give employees "employability security" - that is, opportunities to develop their human capital so they can prosper in the external labor market (Kanter 2001).

Second, the new employment relationship places emphasis on the worker's intellectual and cognitive contribution to the firm. Unlike scientific management, which attempted to diminish or eliminate the role of workers' knowledge in the production process, today's management theories attempt to increase employee knowledge and harness their knowledge on behalf of the firm (Stewart 1997; Davenport 1999).

\footnotetext{
${ }^{21}$ See generally Stone 2006b, at 279-281. See also Barton (2002).

${ }^{22}$ For an analysis of the use of the intermediate category in the United Kingdom, see Davidov (2005). See also Befort (2002) (discussing the development of an intermediate category of dependent independent contractors in Canada, Sweden, and Germany).

${ }^{23}$ According to the United States Department of Labor's Current Population Survey, job tenure for men between 55 and 65 , measured as the average time with a given employer, declined from 15.3 to 10.2 years between 1983 and 2002. For men between 45 and 54, it declined from 12.8 to 9.1 years; for men between 35 and 44, it declined from 7.3 to 5.1 years. Press Release, Bureau of Labor Statistics, U.S. Dep't of Labor, Employee Tenure in 2002 (Sept. 19, 2002), available at http://www.bls.gov/news.release/History/ tenure_09192002.txt.

${ }^{24}$ For a detailed description of the changing workplace, see Stone (2004), at 87-114.
} 
Third, today's employment relationship involves compensation systems that peg salaries and wages to market rates rather than internal institutional factors. The emphasis is on offering employees differential pay to reflect differential talents and contributions. ${ }^{25}$

Fourth, as part of the new employment relationship, firms now also provide employees with opportunities to interact with a firm's customers, suppliers and even competitors. ${ }^{26}$ Regular employee contact with the firm's constituents is touted as a way to get employees to be familiar with and focused on the firm's competitive needs, and at the same to raise the employees' social capital so that they can find jobs elsewhere.

And finally, the new relationship involves a flattening of hierarchy, the elimination of statuslinked perks (See Klein 1994) and the use of company-specific grievance mechanisms. ${ }^{27}$

While the new employment relationship does not depend upon long-term employment, attachment or mutual loyalty between the employee and the firm, it also does not dispense with the need for engaged and committed employees. Indeed, firms today believe that they need the active engagement of their employees more than ever before. They want not merely predictable and excellent role performance, but what has been described as "spontaneous and innovative activity that goes beyond role requirements" (Deckop et al. 1999). They want employees to commit their imagination, energies and intelligence on behalf of their firm.

Today's valuation of employees' cognitive contribution stands in direct contrast to the scientific management approach. Under scientific management, workers were not expected to gain or use knowledge in their jobs. Knowledge was a monopoly tightly held by management. Today, firms believe that they can acquire a competitive advantage by eliciting and harnessing the knowledge of their employees. According to Fortune magazine editor, Thomas Stewart, "Information and knowledge are the thermonuclear competitive weapons of our time" (Stewart 1997).

The emerging employment relationship has two diametrically opposed consequences. On the one hand, it creates a more interesting work environment and offers workers more autonomy and freedom than did the industrial era job structures. Yet on the other hand, for many it creates uncertainty, shifts risk and fosters vulnerability. Some of the groups that are disadvantaged in the new work regime are easily identified. For example, older workers caught in the transition are heavy losers. Having been led to expect a good job and a secure future, they instead discovered that their expectations were chimeral. ${ }^{28}$ Another group that has not fared well is the low-skilled - those who have neither the necessary training nor the ability to reinvent themselves, retool, and adapt to new labor market demands. A third group is the risk-adverse - those who were comfortable in internal labor markets and lack the desire or initiative to seek out opportunities, to network and to build their own careers.

In addition to the older, the unskilled and the risk-adverse, all workers now face heightened risks at certain times in their working lives. Employees can expect to have episodic jobs, sometimes as regular employees, sometimes as temporary workers, and sometimes as independent contractors. Given the churning and constant change that

\footnotetext{
${ }^{25}$ Kanter (1997) (reporting that the tide is moving "toward more varied individual compensation based on people's own efforts").

${ }^{26}$ For example, one of the most touted practices of Total Quality Management is that "management should seek to create conditions whereby every worker, at least from time to time, sees and talks with real customers, with actual users of the company's product or service.” Anschutz (1995).

27 See Greenberg (1996). See generally Colquitt et al. (2001).

${ }^{28}$ For example, a case study of white collar workers laid off at IBM and Link Aerospace in Binghamton, New York - two companies known for their paternalistic long-term employment relationships-concluded that "downsizing and displacement change the expectations about the relationships among workers and between employers and workers." Koeber (2002).
} 
characterizes the new workplace, all face a high likelihood that their working lives will be peppered by occasional periods of unemployment. Therefore, every worker requires a reliable safety net to ease the transitions and cushion the fall that they are likely to encounter in today's boundaryless workplace.

\section{Labor Law and Employment Protection in the Future}

The foregoing historical perspective brings us to the question, what will the labor and employment law look like in the future? In the past, labor and employment laws were enacted as the result of pressure from organized labor and social reformers to ameliorate the vulnerabilities and injustices that occur in the operation of the labor market. The problem today is that the labor and employment laws no longer provide redress for the most pressing problems of workers. The changing nature of work has caused new problems to arise in the operation of the labor market, problems that call for new kinds of regulatory interventions. Today workers move frequently between firms and within firms, so bargaining-unit based unionism gives little protection. And the employment laws do not give adequate protection to the individuals who move in and out of the labor market, or who do not have a typical relationship with a single employer.

There are two possible scenarios for the future of labor law. One scenario is that labor law will continue to atrophy, unions will continue to decline and individual employee rights will be chipped away through the combined processes of narrowing judicial construction of existing rights, the development of a robust waiver doctrine whereby employees will have rights on paper but not in practice, pressures from globalization for lower labor standards and a slow erosion of specific monetary standards through inflation. This scenario is a likely one given the declining power of unions at the legislative level that results from labor's declining numerical strength. Union political power is necessary to pressure politicians to maintain employment standards at current levels or raise them higher. In this first scenario, worker rights will decline in all the respects just mentioned, and we will see a return to the laissez-faire labor regulation of the pre-Wagner Act era.

The other scenario is that labor laws will evolve in a way that represents a marked break with the present in order to address the needs and concerns of individuals in the new workplace. I predict that changes will come in some or all of these respects:

- a partial collapse of the distinction between labor law and employment law;

- an expanded focus on the legislative front rather than on collective bargaining to set employment conditions

- an expansion of collective bargaining to new groups, such as independent contractors, atypical workers, immigrants, unemployed workers and geographically defined groups;

- a broadening the field of labor and employment law to include all issues of concern to working people, such as health care policy, training and education, welfare, intellectual property protection, pensions and social security, housing policy and other areas of social law; and

- the creation of a new type of social safety net to focus on the problem of transitions and gaps in people's labor market experiences

Collapsing the Distinction Between Labor and Employment Law

As stated above, the U.S. system of employment regulation has maintained a distinction between the collective bargaining rights for unionized workers and individual employment 
rights for other workers. Though this distinction sounds fixed in theory, there has in fact always been a permeable boundary between these bodies of regulation. ${ }^{29}$

Recent developments have further challenged this distinction. Increasingly, workers with individual employment law claims have brought their claims in a collective form, either as class actions under most employment statutes, or as "collective actions" under the Fair Labor Standards Act. Class actions have long been a feature of employment discrimination litigation, but now they have spread to other types of employment law claims. Collective actions under the FLSA are similar to class actions, but in some respects, the requirements for a "collective action" are easier for plaintiffs to satisfy than those for a class action under Rule 23 of the Federal Rules of Civil Procedure. ${ }^{30}$ Collective employment litigation has been brought in both state and federal courts, alleging violations of both state and federal labor laws. ${ }^{31}$

Employment class actions occupy the vast majority of work of management-side employment law firms. As one observer writes, "A sample of 150 FLSA 'collective action' cases prosecuted by the Department of Labor as of January 2005 reads like a Who's Who of corporate America, including Wal-Mart (seven times in the previous 5 years); Bed, Bath \& Beyond; Nortel Networks; Safeco Insurance Companies (twice); Pep Boys; Electronic Arts, Inc.; Minolta Business Solutions; Countrywide Credit Industries; Conseco Finance Corp.; NBC; Ameriquest Mortgage Co. (three times); First Union Corp.; and, Perdue Farms. Public entities being sued included the City of Louisville and the Chicago Transit Authority. The majority of these claims were misclassification cases, mostly for unpaid overtime." 32 This list does not include private collective employment actions brought by individual or groups of employees.

Employment law collective actions can result in sizeable damage awards. For example, in recent wage and hour suits in California alone, the Coca-Cola Bottling Company settled a case for \$20.2 million, Bank of America settled for \$22 million and Rite Aid Corp. settled for $\$ 25$ million (Hechler 2001). In 2002, United Parcel Service agreed to pay $\$ 18$ million to settle a similar suit on behalf of misclassified supervisors (Ogletree et al. 2002). The same year, Starbucks Corp. also paid $\$ 18$ million to settle two class action suits on behalf of current and former managers and assistant managers in California who claimed that they had been misclassified as "exempt" employees and thereby denied overtime compensation.

Collective employment litigation, whether brought as class actions or as FLSA collective actions, is an expanding form of collective action in an era of declining union activity. While such actions do not foster the experience of solidarity and collective empowerment that characterize unionization efforts and strikes, they share some features with other

\footnotetext{
${ }^{29}$ The labor law Section 301 preemption doctrine serves as the primary traffic cop that directs individuals with work-related disputes to one body of law or the other. However, the preemption doctrine itself has been an evolving and changing set of rules, so that some individual rights can be vindicated by individuals who have union contracts, and some cannot. See Stone (1992).

${ }^{30}$ Collective actions under the FLSA are provided for at 29 U.S.C. $\S 216$. They do not have the same stringent requirements for numerosity and typicality that are imposed by Rule 23 of the Federal Rules of Civil Procedure for class actions, so it is easier for a collective action to be maintained under the FLSA.

${ }^{31}$ Examples of state law class actions brought under a state employment law are Armenta v. Osmose, Inc., 37 Cal. Rptr. 3d 460 (2005) (California minimum wage law); Gafur v. Legacy Good Samaritan Hosp. and Medical Center, 344 Or. 525, — P.3d —-, 2008 WL 2054448 (Or.,2008) (Oregon law requiring rest breaks); Bell v. Superior Court, 69 Cal.Rptr.3d 328 (Cal.App. 2 Dist.,2007) (California overtime and rest break laws).

${ }^{32}$ Miller (2007) (unpublished manuscript, on file with the author) (citing Alaimo et al. 2005).
} 
conventional forms of collective action. They reflect a shared sense of work related wrong and they define a group of workers - the class - as having a shared interest. They also operate through representatives, the named plaintiffs and the class counsel, who speak to management for the workers and, at least in theory, represent their interests. Collective employment actions are greatly feared by management because, apart from their potential exposure, the suits are on-going disputes with incumbent disgruntled employees who are potentially poisonous to general workplace morale. ${ }^{33}$

Class actions also have some obvious and significant differences with conventional unionization efforts. First, they do not involve the type of mobilization that typically occurs in a union drive. Furthermore, they do not aim to form lasting organizations nor do they offer the prospects of an on-going bargaining relationship between workers and an employer over the whole range of issues involved in the employment relationship. They take a long time to run their course, but essentially they are one-shot, single issue challenges to a company's employment practices. And they also do not generally foster the type of bonds of solidarity on which conventional unionism relies. ${ }^{34}$ And finally, they seek to vindicate pre-existing statutory rights, not to define the normative rules that shall govern the workplace. That is, unlike collective bargaining, they are not an exercise in labormanagement self-regulation.

It is interesting to note that the features of collective employment actions that distinguish them from collective bargaining parallel the broad changes in the employment relationship described above. In collective litigation, relatively atomistic employees come together to fight on one issue. Some class members may not be employed by the defendant at the time of the lawsuit, and the members of the class often have never met each other. Once the suit is over, any bonds of solidarity dissolve. This one-shot activism is compatible with the mobile, self-contained knowledge worker that is the paradigm of today's worker. Hence it is possible that ex post single issue workplace governance is the form that collective action will continue to take in the future. ${ }^{35}$

Despite the differences between collective employment litigation and collective bargaining, as unions decline collective litigation has become an important venue for the protection of employment rights. Their profusion suggests that this may be an important form of employee collective action for the future. If that is the case, then the specific legal requirements of maintaining a collective legal action-whether a class action or a FLSA collective action-will come under increased scrutiny. For example, in some employment discrimination litigation, courts have begun to consider how to apply Rule 23(b)'s commonality and typicality requirements to workplaces in which management authority is diffuse and delegated to lower-level supervisors. ${ }^{36}$ This issue is posed presently in the behemoth employment discrimination case, Dukes v. Wal-Mart Stores, involving 1.5 million

\footnotetext{
${ }^{33}$ This point was made to me in conversation by the head of employment litigation for one office of the Jackson Lewis law firm, one of the largest employer-side employment law firms in the United States.

${ }^{34}$ For an incisive account of the relationship between unionism and solidarity, see Offe and Weisenthal (1985).

${ }^{35}$ I am grateful to Fred Tung for this insight.

${ }^{36}$ Compare Allen v. Chicago Transit Authority, No. 99C7614, 2000 WL 1207408 (N.D. Ill.. July 31, 2000) (finding no commonality and hence refusing to certify class action where the company had neither a highly centralized nor entirely subjective method of determining promotions) with McReynolds v. Sodexho Marriott Services, Inc., 208 F.R.D. 428 (D.D.C. 2002) (certifying class action alleging employment discretion despite the company's decentralized decision-making structure and lack of uniform promotion policy). See generally Stone (2004, at 174-178).
} 
present and former Wal-Mart employees. ${ }^{37}$ There are also debates about the requirement in FLSA collective actions that class members "opt in" rather than "opt out" as is permitted under Rule 23. ${ }^{38}$ As employment class actions continue to proliferate, these procedural requirements will take on added significance.

Another feature of collective employment litigation is the involvement of unions. More and more, unions are financing and otherwise assisting unorganized workers in mounting employment class actions. For example, the United Food and Commercial Workers Union has been actively involved in wage and hour suits against Albertson's grocery chain, Tyson Foods, Perdue Farms and the Nordstrom retail chain (Hechler 2001). The Writers' Guild sponsored several wage and hour class action lawsuits against television reality shows even though the employees involved were not represented by the union. ${ }^{39}$ Some have argued that by assisting these types of actions, unions can gain a foothold in unorganized workplaces that could lead to greater organizing success down the road. While there is no evidence to date that this has occurred, it remains a hopeful prospect for a labor movement that is experiencing hemorrhaging losses.

Before we can conclude that collective employment actions are either a substitute for actual unionization or a foot-in-the-door method to revitalize the union movement, it is necessary to look at some legal issues that are waiting in the wings. One issue that has arisen is whether a union, by giving unorganized workers financial assistance in the form of legal representation in employment litigation, is giving an unlawful benefit to improperly influence workers' choice whether or not to unionize. Some court decisions have held that when a union finances an employment litigation, it is an unlawful payment of benefits and hence grounds to set aside a union election. ${ }^{40}$ Another issue that might arise is whether a union that participates in the negotiation of a settlement of an employment class comprised of unorganized workers is acting in a representative capacity without having attained majority status. In such a case, its actions would also violate the statute. If union involvement in employment class actions is to be an important tactic in the future of the union movement, the labor law will need to address these issues.

\section{Shifting from Collective Bargaining to Legislation to Set Employment Conditions}

In recent years, as unions have declined, more statutory employment rights have been created that are applicable to all workers. In addition, the nature of legislated individual employment rights has shifted from a floor to a baseline. That is, the more recent employment standards are not designed to set bare minima, but to set an adequate baseline

\footnotetext{
${ }^{37}$ Dukes v. Wal-Mart Stores, Inc., 222 F.R.D. 137 (N.D. Cal. 2004), aff'd Dukes v. Wal-Mart Stores, Inc., 474 F. 3d 1214 (9th Cir. 2007), withdrawn and superseded by Dukes v. Wal-Mart Stores, Inc., 509 F. 3d 1168 (9th Cir. 2007) (affirming lower court's class certification).

38 See, e.g., Ruckelshaus (2008); Lampe and Rossman (2005).

${ }^{39}$ Sharp v. Next Entm't, No. BC 336170 (Cal. Super. Ct. L.A. County filed July 7, 2005) and Shriver v. Rocket Sci. Labs., LLC, No. BC 338746 (Cal. Super. Ct. L.A. County filed Aug. 23, 2005). See generally Bronstad (2005, at 10).

${ }^{40}$ See Freund Baking v. NLRB, 165 F.3d 928 (D.C. Cir. 1999); Nestle Ice Cream Co. v. NLRB, 46 F.3d 578 (6th Cir. 1995). But see, Novotel New York, 321 NLRB 624, 152 L.R.R.M. (BNA) 1201 (1996) (refusing to find union's conduct in bringing FLSA lawsuit on behaof of unorganized employees to be objectionable or grounds to set aside election.). See also, General Counsel Advice Memo, United Food and Commercial Workers Union, Local 120 (Wal-Mart Stores, Case 32-CB-5757-1 (October 13, 2004), 2004 WL 2414080 (N.L.R.B.G.C.). See generally, Fisk (2002) (discussing legality of union representation of non-union workers in wage and hour litigation).
} 
level of protection. For example, the Occupational Safety and Health $\mathrm{Act}^{41}$ imposes a general duty on employer to provide each worker a work environment that is free from identified hazards. ${ }^{42}$ Similarly, workplace privacy protections and employment discrimination legislation is designed to ensure individuals a workplace that is free of discrimination and respectful of employee privacy. This is not to say that these and other employment rights are set at an optimal or even a truly adequate level. For example, the Family and Medical Leave Act mandates a minimal period of leave for child-bearing, but does not mandate pay replacement for the period of the leave. But unlike the original New Deal employment rights, the more recent statutory rights are intended to apply to a majority of workers, not merely those at the margins of subsistence.

The change in the nature of employment rights and the increase in rights for all employees represent a shift in the locus of employment regulation away from collective bargaining and toward the state. The shift from collective bargaining to legislation does not necessarily signal the end of unionism, but rather could auger a change in union strategy and tactics. Unions may shift their focus from exerting employer-specific pressure to exerting pressure in the political arena, including federal, state and local. This would represent a significant departure from the U.S. labor movement's traditional position, dating back to Sam Gompers in the 1890 s, that union pressure was most effective in the economic realm rather than in the political realm. But today, as discussed above, employer-centered union pressures are rendered less effective than they were in the past because employees have little attachment to either a specific employer or a particular craft group. Should unions concentrate more on the political realm, they will also be forced to articulate their goals in the vernacular of the public interest rather than as the demands of a special interest group. Hence they may reclaim their role as spokesperson for the working population generally.

In terms of the future of employment law, we can expect not only more employment laws, but also more controversy about them. Campaign finance rules regarding union campaign contributions, and labor law rules regarding use of union funds for political purposes, have generated enormous amounts of litigation in recent years, and we can expect those controversies to intensify. ${ }^{43}$

\section{Expanding Collective Bargaining to New Groups, Particularly Geographically Defined Groups}

There is evidence that employees feel they need unions, but not necessarily the unions that now exist (Freeman and Rogers 1999). Given the decline of worker-firm attachment, workers need organizations that further their joint interests but that are not pegged to a particular employer. Because workers move frequently within and between firms throughout their working lives, there needs to be a mechanism for workers to deploy their collective power to negotiate conditions across employers.

At the present time, there are some new types of organizations that attempt to engage in bargaining with multiple employers in different industries and utilizing workers with differing skills. For example, in many cities, unions have worked with community groups to enact living wage ordinances to improve labor standards for low-wage public sector

\footnotetext{
4129 U.S.C. $\$ \S 651-678(2000)$.

${ }^{42} I d . \S 654(\mathrm{a})(1)$.

${ }^{43}$ M. Masters, R. Gibney \& T. Zagneczyk, Worker Paycheck Protection: Implications for Labor's Political Spending and Voice, Industrial Relations (2008) [forthcoming]; M. Masters and R. Jones, The Hard and Soft Sides of Union Political Money, 20 J. of Labor Research, 297-340 (1999).
} 
employees (See Stone 2006a). Presently there are city-wide living wage ordinances in Baltimore, Los Angeles and other places as a result of area-wide political pressures by community and labor groups. Although such ordinances are limited to public sector employees, they suggest a new form of bargaining for workers across industries on a locality-wide basis. We could envision city ordinances that set industrial safety codes, mandate paid family leave, require employers to provide health insurance and address other issues that are part of the shared needs of all working people in the area.

In a similar vein, in Los Angeles, San Antonio and some other cities, unions and community groups have worked together to negotiate agreements with city authorities and private investors to provide job creation, job training, affordable housing, social services, public parks and other community improvements in exchange for support for development projects. ${ }^{44}$ There have also been multiple-employer organizing efforts of immigrant workers within particular sectors. ${ }^{45}$ In many cities, worker centers have developed to inform low wage workers, often immigrants, of their legal rights. ${ }^{46}$

The present labor law does not easily accommodate area-wide multi-employer, multisector bargaining, particularly when it involves union-community partnerships on one side, and multiple employers and city agencies on the other. However, organizations that engage in such efforts could provide important benefits for workers in today's labor market. Although workers change jobs more than in the past, they usually find new jobs in the same geographic area of their previous jobs. Hence it would be desirable for the labor law to facilitate areawide bargaining on such issues as minimum pay levels, health and pension benefits, leave policies, safety standards, job training programs, job transfer rights and employment benefits at the local and/or regional level. To do so, the labor law would have to abandon the present notion of bargaining units, and devise another mechanism for determining legally sanctioned bargaining rights. Proposals for geographic unions, such as put forward by Charles Heckscher, Raymond Miles, and this author, can serve as a starting point. ${ }^{47}$

\section{Broadening the Labor and Employment Law Field}

The field of labor and employment has until now been seen as narrowly related to issues that arise in the employer-employee relationship in the workplace. However, given today's fluid and boundaryless workplace, issues concerning work do not always involve workers' relationships to their immediate employer. Rather, many other areas of law affect one's relationship to the labor market. These include issues such as health insurance, training and education, welfare assistance, pensions and social security. Also, there are new issues that have arisen for workers as a result of the new employment practices.

For example, one legal issue that was invisible in the past but has become prominent today is the issue of who owns an employee's human capital. Because the new employment relationship relies on employees' intellectual, imaginative and cognitive contribution to the firm, employers put a premium on human capital development and knowledge-sharing within the firm. Yet the frequent lateral movement between firms that typifies the new

\footnotetext{
${ }^{44}$ For a detailed account of the union-community alliances and the negotiation of a "community benefits agreement" in Los Angeles, see Cummings (2006). On similar efforts undertaken by the Industrial Areas Foundation in San Antonion and other cities in Texas, see Osterman (2002).

45 See, e.g., Milkman (2006).

46 See, e.g., Gordon (2005); Fine (2006).

${ }^{47}$ See Miles (1989) (advocating a turn to geographically based unionism); Heckscher (1988); Stone 2004, at 217-39. For details about the labor law changes that such proposals would require, see Stone, id. at 237-39.
} 
relationship means that when an employee leaves one employer and goes to work for a competitor, there is a danger that proprietary knowledge will go too. Increasingly, the original employer, fearing that valuable knowledge possessed by the employee will fall into the hands of a competitor, will seek to prevent the employee from taking the job or utilizing the valuable knowledge. Yet employees understand that their employability depends upon their knowledge and skills, so they assume that they can take their human capital with them as they move between jobs. As a result of these conflicting perspectives, legal disputes about post-employment covenants and trade secrets have increased exponentially, making them the most frequently litigated issues in employment law.

\section{Creating a New Type of Safety Net Such as Workplace Sabbatical/Social Drawing Rights}

In the future, it will be important to create a new type of social safety net, one tailored to the vulnerabilities of today's workplace. Because most workers will experience discontinuities in their labor market experiences, they need provision for gaps and transitions. They need portable health benefits, lifetime training and retraining opportunities, universal and adequate old age assistance, and other forms of assistance for individuals who are in periods of transition between jobs or changing careers.

To date, neither our welfare laws nor our labor and employment laws have focused on the problem of transition assistance. However, the issue has been actively considered in Europe. In 1999, the European Commission convened distinguished a group of labor relations experts to consider the implications of the changing nature of work on labor regulation in Europe and to devise proposals for reform. In 2000, the group, chaired by Professor Alain Supiot, issued a report that described a changing employment landscape as a result of the movement away from internal labor markets toward more flexible industrial relations practices. The Supiot Report called for new mechanisms to provide workers with "active security" by which they mean mechanism that equip individuals to move from one job to another. ${ }^{48}$ It contained a number of suggestions for changes in the institutions regulating work to provide active security. Its most visionary proposal was for the creation of "social drawing rights" to facilitate worker mobility and to enable workers to weather transitions. Under the proposal, an individual would accumulate social drawing rights on the basis of time spent at work that could be used for paid leave for purposes of obtaining training, working in the family sphere, or performing charitable or public service work. It would be a right that the individual could invoke on an optional basis to navigate career transitions, thereby giving flexibility and security in an era of uncertainty. As Supiot writes, "They are drawing rights as they can be brought into effect on two conditions: establishment of sufficient reserve and the decision of the holder to make use of that reserve. They are social drawing rights as they are social both in the way they are established...and in their aims (social usefulness)."49

The Report makes an analogy to sabbatical leaves, maternity leaves, time off for union representatives and training vouchers to observe that "we are surely witnessing here the emergence of a new type of social right, related to work in general." ${ }^{\text {"S0 }}$ Social drawing rights, it is said, would smooth career transitions and give individuals the resources to retool and to weather the unpredictable cycles of today's workplace.

\footnotetext{
${ }^{48}$ See Supiot et al. (2001); Supiot et al. (1999), See also Marsden and Stephenson (2001).

${ }^{49}$ Supiot et al., Beyond Employment, supra note 46, at 56.

${ }^{50} \mathrm{Id}$.
} 
In the United States, we have precedents for the concept of paid time off with reemployment rights to facilitate career transitions or life emergencies. We have long permitted paid leaves for military service, jury duty, union business, and other socially valuable activities. Some occupations also offer periodic sabbatical leaves. The concept is also built into the idea of temporary disability in state workers compensation and other insurance programs, which provide compensation and guarantee re-employment after for temporary absences. The recent Parental Leave Act extends the concept of leave time to parenting obligations. These programs all reflect and acknowledge the importance of subsidized time away from the workplace to facilitate a greater contribution to the workplace. They could serve as the basis for developing a more generalized concept of career transition leave, or to use more familiar parlance, a workplace sabbatical.

A workplace sabbatical would be a right, accrued by time spend in the labor force, to paid leave for the purpose of retooling, retraining and repositioning oneself in the labor market. This right should be made a part of the contract of employment similar to a right to unemployment compensation. The workplace sabbatical right should not be an implied in fact term of the contract of employment - that is, it should not depend upon an employer implicitly promising employability, training and networking opportunities, and it should not be waivable. Rather, the right to a workplace sabbatical should be an implied-in-law term that it grows out of the recognition that workers today are vulnerable to changing technological demands, and need opportunities to change and develop their human capital as they face a lifetime of job transitions. The justification for imposing such a term is that it tracks the normative as well as practical reality of today's workplace.

\section{Conclusion}

The workplace is changing and the labor and employment laws will change as well. Workers today are forced to bear many new risks in the labor market - risks of job loss, wage variability, benefit gaps, skill obsolescence and intermittent prolonged periods of unemployment. Currently our labor and employment laws do not address these problems, either for regular or for atypical workers. The changing nature or work has rendered much of the labor and employment law framework obsolete, and a new framework will be created to take its place. It remains to be seen whether the new framework will be a free market framework of laissez faire capitalism, or whether it will be the creation of a new type of rights and safety net that enables workers to thrive in the new workplace.

Open Access This article is distributed under the terms of the Creative Commons Attribution Noncommercial License which permits any noncommercial use, distribution, and reproduction in any medium, provided the original author(s) and source are credited.

\section{References}

Alaimo, M. A., et al. (2005). Emerging FLSA trends: class actions, enforcement, and new regulations. Michigan Bar Journal, 84, 15. 
Anschutz, E. E. (1995). TQM America: how America's most successful companies profit from total quality management 53.

Ball, P. (2003). The new traditional employment relationship: an examination of proposed legal and structural reforms for contingent workers from the perspectives of involuntary impermanent workers and those who employ them. Santa Clara Law Review, 43, 901 Comment.

Barton, L. H. (2002). Reconciling the independent contractor versus employee dilemma: a discussion of current developments as they relate to employee benefit plans. Capital University Law Review, 29, 1079.

Befort, S. F. (2002). Labor law and employment law at the millennium: a historical review and critical assessment. British Colombia Labor Review, 43, 351.

Bronstad, A. (2005). More 'Story Tellers' claim overtime. Los Angeles Business Journal, 27, 10 Aug. $29,2005$.

Brudney, J. J. (1996). Reflections on group action and the law of the workplace. Texas Law Review, 74, 1563.

Brudney, J. J., et al. (1999). Judicial hostility toward labor unions?: Applying the social background model to a celebrated concern. Ohio State Law Journal, 60, 1675.

Brustein, A. H. (2005). Casual workers and employee benefits: staying ahead of the curve. University of Pensylvania Journal of Labor \& Employment Law, 7, 695 Comment.

Colquitt, J., et al. (2001). Justice at the millennium: a meta-analytic review of 25 years of organizational justice research. Journal of Applied Psychology, 86, 425, 435-436.

Colvin, A. (1998). Rethinking bargaining unit determination: labor law and the structure of collective representation in a changing workplace. Hofstra Labor \& Employment Law Journal, 15, 419, 430-431.

Cummings, S. L. (2006). Mobilization lawyering: community economic development in the Figueroa Corridor. In A. Sarat \& S. A. Schiengold (Eds.), Cause lawyers and social movements (pp. 302, 313-324). Palo Alto, CA: Stanford University Press.

Dannin, E. (2004). Finding the workers' law. Green Bag 2d, 8, 19, 27.

Dannin, E. J., \& Bonior, D. E. (2006). Taking back the workers' law: how to fight the assault on labor rights. Ithaca, NY: ILR Press.

Davenport, T. O. (1999). Human Capital: what it is and why people invest in it 152-56. Hoboken, NJ: Jossey-Bass.

Davidov, G. (2005). Who is a worker? Industrial Labor Journal, 34, 57.

Deckop, J. R., et al. (1999). Getting more than you pay for: organizational citizenship behavior and pay-forperformance plans. Academic Management Journal, 42, 420.

Doeringer, P., \& Piore, M. J. (1971). Internal labor markets and manpower analysis. New York, NY: M.E. Sharpe, Inc.

Dunlop, J., Kerr, C., Lester, R., \& Reynolds, L. (1988). How labor markets work: reflections on theory and practice. Bruce E. Kaufman (Ed.). Lanham, MD: Lexington Books.

Estlund, C. L. (2002). The ossification of American labor law. Columbia Labor Review., 102, 1527.

Fine, J. (2006). Worker centers: organizing communities at the edge of the American Dream. Ithaca, NY: Cornell University Press.

Fisk, C. L. (2002). Union lawyers and employment law. Berkeley Journal of Employment and Labor Law, $23,57$.

Freeman, R. B., \& Rogers, J. (1999). What workers want. Ithaca: Cornell University Press.

Getman, J. G., et al. (1999). Labor management relations and the law 30-31, 2d ed. Eagan, MN: Foundation Press.

Gordon, J. (2005). Suburban sweatshops: the fight for human rights. Cambridge, MA: Harvard University Press.

Gottesman, M. H. (1993). In despair, starting over: imagining a labor law for unorganized workers. ChicagoKent Law Review, 69, 59.

Graditor, L. L. (2003). Back to basics: a call to re-evaluate the unemployment insurance disqualification for misconduct. John Marshall Law Review, 37, 27, 60-61.

Greenberg, J. (1996). The quest for justice on the job 32-39. Thousand Oaks, CA: Sage Publications.

Hechler, D. (2001). Suits by workers over wages increase. National Law Journal, 24, A15.

Heckscher, C. C. (1988). Associational Unionism. In The New Unionism: employee involvement in the changing corporation 177. New York, NY: Basic Books.

Hiatt, J., \& Becker, C. (2005). At age 70, should the Wagner Act be retired? Berkeley Journal of Employment and Labor Law, 26, 293, 307.

Kanter, R. M. (1997). On the Frontiers of Management 175. Boston, MA: Harvard Business School Press.

Kanter, R. M. (2001). Evolve! Succeeding in the Digital Culture of Tomorrow 192. Boston, MA: Harvard Business School Press.

Klein, J. (1994). The paradox of quality management: commitment, ownership, and control. In C. Heckscher \& A. Donnellon (Eds.), The post-bureaucratic organization: new perspectives on organizational change (pp. 178-182). Thousand Oaks, CA: Sage Publications. 
Koeber, C. (2002). Corporate restructuring, downsizing, and the middle class: the process and meaning of worker displacement in the "New" economy. Qualitative Sociology, 25, 217, 219.

Lampe, M. W., \& Rossman, E. M. (2005). Procedural approaches for countering the dual-filed flsa collective action and state-law wage class action. Labor Law, 20, 311, 313-316.

Marsden, D., \& Stephenson, H. (Eds.). London School of Economics, Centre for Economic Performance, Labour Law and Social Insurance in the New Economy: A Debate on the Supiot Report, Discussion Paper No. CEPDP0500 (July 2001), available at http://cep.lse.ac.uk/pubs/download/DP0500.pdf.

Masters, M. M., \& Jones, R. (1999). The hard and soft sides of union political money. Journal of Labor Research, 20, 271.

McGarity, T. O., \& Shapiro, S. A. (1996). OSHA's critics and regulatory reform. Wake Forest Law Review, $31,587$.

Miles, R. E. (1989). Adapting to technology and competition: a new industrial relations system for the 21 st century. California Management Review, 31, 9, 23-25.

Milkman, R. (2006). L.A. Story: immigrant workers and the future of the U.S. Labor Movement.

Miller, S. Class action, collective action, and collective bargaining (May 2007) (unpublished manuscript, on file with the author).

Offe, C., \& Weisenthal, H. (1985). Two Logics of Collective Action. In J. Keane (Ed.), Disorganized Capitalism: contemporary Transformations of Work and Politics 170. Cambridge, MA: M.I.T. Press.

Ogletree, Deakins, Nash, Smoak \& Stewart, P.C., (2002). Another Day, Another Multimillion-Dollar Settlement. California Employment Law Letter, 12, 3 (Nov. 11, 2002).

Osterman, P. (1984). Internal Labor Markets 2. Cambridge, MA: M.I.T. Press.

Osterman, P. (2002). Gathering power: the future of progressive politics in America. Boston, MA: Beacon Press.

Ruckelshaus, C. R. (2008). Labor's wage war. Fordham Urb. L.J., 35, 373, 386-388.

Stewart, T. A. (1997). Intellectual Capital: the New Wealth of Organizations, at ix. New York, NY: Doubleday.

Stone, K. (1975). The origin of job structures in the steel industry. In R. C. Edwards, et al. (Eds.), Labor Market Segmentation 27. Lantham, MD: Lexington Books.

Stone, K. V. W. (1992). The legacy of industrial pluralism: the tension between individual employment rights and the new deal collective bargaining system. University of Chicago Law Review, 59, 575.

Stone, K. V. W. (2004). From widgets to digits: employment regulation for the changing workplace 4-7. Cambridge: Cambridge University Press.

Stone, K. V. W. (2006a). Flexibilization, globalization, and privatization: three challenges to labour rights in our time. Osgoode Hall Law Journal, 44, 77, 98-99.

Stone, K. V. W. (2006b). Legal protections for atypical employees: employment law for workers without workplaces and employees without employers. Berkeley Journal of Employment and Labor Law, 27, 251, 279-281.

Summers, C. W. (1988). Labor Law as the century turns: a changing of the guard. Neb. L. Rev., 67, 7, 10.

Supiot, A., et al. (2001). Beyond employment: changes in work and the future of labour law in Europe 56. Oxford: Oxford University Press.

Supiot, A., et al. (1999). A European perspective on the transformation of work and the future of labor law. Comparative Labor Law \& Policy Journal, 20, 621-628. 